\title{
Impact of Smartphones Usage on the Learning Behaviour and Academic Performance of Students: Empirical Evidence from Pakistan
}

Faheem Shakoor, Ayesha Fakhar, Jawad Abbas

To Link this Article: http://dx.doi.org/10.6007/IJARBSS/v11-i2/8902

DOI:10.6007/IJARBSS/v11-i2/8902

Received: 11 January 2021, Revised: 05 February 2021, Accepted: 17 February 2021

Published Online: 26 February 2021

In-Text Citation: (Shakoor et al., 2021)

To Cite this Article: Shakoor, F., Fakhar, A., \& Abbas, J. (2021). Impact of Smartphones Usage on the Learning Behaviour and Academic Performance of Students: Empirical Evidence from Pakistan. International Journal of Academic Research in Business and Social Sciences, 11(2), 862-881.

Copyright: (c) 2021 The Author(s)

Published by Human Resource Management Academic Research Society (www.hrmars.com)

This article is published under the Creative Commons Attribution (CC BY 4.0) license. Anyone may reproduce, distribute, translate and create derivative works of this article (for both commercial and non-commercial purposes), subject to full attribution to the original publication and authors. The full terms of this license may be seen at: http://creativecommons.org/licences/by/4.0/legalcode

Vol. 11, No. 2, 2021, Pg. 862 - 881

Full Terms \& Conditions of access and use can be found at http://hrmars.com/index.php/pages/detail/publication-ethics 


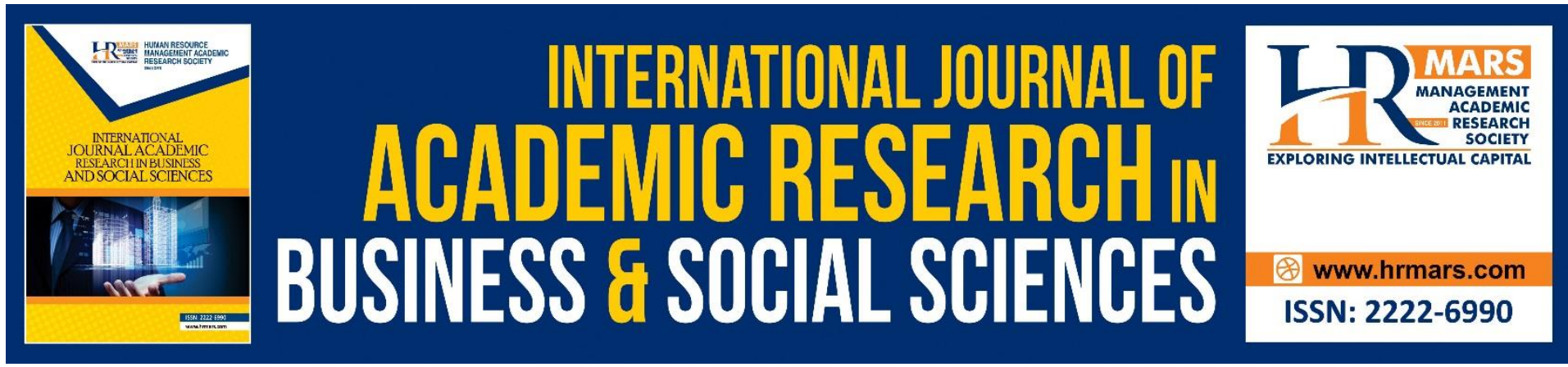

\title{
Impact of Smartphones Usage on the Learning Behaviour and Academic Performance of Students: Empirical Evidence from Pakistan
}

\author{
Faheem Shakoor, Ayesha Fakhar, Jawad Abbas \\ Department of Business Administration, Iqra University, Islamabad Campus, Pakistan \\ Email: faheem.shakoor19303@gmail.com
}

\begin{abstract}
Students are the main users and sensitive to the smartphone and it affects the general population because of their persuasiveness. Several results show that there is a positive correlation between smartphone usage and academic performance since they lead to the behaviours that affect student's careers and learning behaviour, e.g. addictedness, excess screen usage. However, these studies only focus on smartphone usage behaviour which only provides some usage patterns. We propose to fulfil the gap by measuring smartphone usage and academic performance by combining them both to keep track of users. We analyse this study by study on 150 students studying in Islamabad enrolled in different departments. They all used Smartphones in their daily life routine to learn academic content and lectures. By analysing the results, we provide a quantitative estimate of positive and negative results and correlations. Our result shows the positive correlation and impact of smartphone usage on academic performance.
\end{abstract}

Keywords: Smartphones, Academic Performance, Social Media, Learning Behaviour, Higher Education.

\section{Introduction}

In today's modern world, technological advancements change the behaviour and system of consumption of people around the world (Mahmood et al., 2020). Information and communication technology (ICT) influences the learning behaviour and system of gaining knowledge according to the modern situation (Abbas et al., 2014). In these advancements, a smartphone is a device, similar to a computer operating system, having computing abilities and connectivity options. These were released in 2000, and from that period they became some popular and desirable gadgets for everyone. Smartphones have successfully replaced desktop computers for a number of activities because it's a small smart device that everyone can easily keep inside a pocket. It has become an integral part of today's generation in every aspect of life especially for students and youngsters who are the major users or consumers of smartphones (Hossain, 2019).

We observe that, with the emergence of the modern industrial revolution, especially educational reforms, the use of ICT devices has gained more attention (Abbas, 2020b). In these devices, smartphones have arisen as one of the most prevalent for communication and 
multipurpose devices. Technological advancement has changed the way we use the information. Studies show that almost $63 \%$ of students owned smartphones in North America, moreover half of them admitted that they use their smartphones to access the internet via Wi-Fi and cellular data to access social networking sites and emails to access their mails and academic articles. A smaller but growing number of students in the US shows that they use smartphones to operate online banking, online shopping, and entertainment purpose. Now a day, electronic gadgets especially smartphones getting importance and prove essential for students in their academic period and learning process (Abbas, 2020c). Also, the concerning point is that these devices also dominate their life by providing them with relevant information and data anywhere anytime. This information can be accessed and retrieved by mobile phones via applications, e-books, journals, search engines, and social media sites. People use these gadgets to access easy internet for a different online learning process (AlEmran et al., 2016).

Google's modern study shows that all major countries around the world including Australia, United Kingdom (UK), Saudi Arabia, Norway, Sweden and United Arab Emirates (UAE) have smartphones adoption proportions more than 50\%. Different people use smartphone devices according to their unique individual choices, like many people use it for entertainment purpose in their leisure time and many businessmen use smartphones to increase their business activities by the help of smartphones by availing the facilities like online banking, managing records of items on smartphones, schedule meetings and preparing reports and presentations on their handy smartphone (Habib et al., 2019). In today's modern world, our traditional classrooms were changed into online remote classrooms in which students are available through the online session from their smartphones and teachers or lecturer gives a lecture to their students remotely from anywhere around the world. According to the study, the higher adoption rate of smartphones is seen among University students who are in the bachelor's program and these university students are known as the "SWEET SPOT" market segment (Arif et al., 2016).

Studies reveal that development in the latest modern electronic information resources creates new challenges in the information-seeking manners of students (Ahsan et al., 2020). The level of accessibility of information will affect the instant satisfaction found to be an important factor in smartphone attractiveness among students. However, all these studies regarding the effects on studies, some other concerns also need to be pointed. Of the wide concern to the many instructors, smartphones cause potential destruction to the students by playing games, texting, using social media in classrooms, or any other activity using phones available to them in a quickly growing digital environment. Furthermore, $64 \%$ of teens students who possess smartphones have texted during class lectures, even in lowgrade schools where smartphones are officially banned. Those texts come at the expense of learning and education, as indulging in texting during class lectures reduces student's ability to self-regulates and give constant attention to classroom tasks (Nayak, 2018).

Thus considering a gap in the studies, we aim to find learning behaviour and effects on students' academic performance in this research, we focus on the usage behaviour and intensity of smartphones among students and the major activities that they have performed by using their smartphones. These activities include general activity to specific educational and academic activities. There are so many events included in the academic purpose which are covered in the survey questionnaire. We try to find out the relationship between different variables, like the usage of smartphones and the academic performance of students and 
learning behaviour comprising of both male and female, and different age groups wise according to their qualifications and discipline.

\section{Research Objectives}

There are certain objectives and aims of this study which are described below

- To discover the connection between Smartphone technology usage and academic performance among university students.

- Observing the influence of smartphones on both male and female's academic performance separately.

- What activities students prefer to do by their smartphones for their learning process

- For what purposes, students use smartphones the most.

\section{Literature Review}

Mobile phone devices are not communication devices anymore; they have included a variety of features and functions that were not possible some years ago. These features make the mobile phone transform into a Smartphone. Smartphone devices are getting popular among every age group of people especially youngsters who are college or university students, they are the early adopter of these technologies (Abbas et al., 2015). Multiple arguments are existing over the previous literature and research studies for an association. Both positive and negative effects have been found among smartphone consumption and academic performance. According to the study, they can access the internet, send and receive text messages from their social circle, check emails and even video chat with their friends and family from the tips of their hands. Also, we observe that students use social media sites and applications, online libraries and portals from their smartphones which helps to enhance their learning process (Mahmood et al., 2014). The increasing trends and development of mobile learning resources and E-libraries improved the value of smartphones and also enhance the information-seeking behaviour of students (Abbas et al., 2014; Kuznekoff and Titsworth, 2013).

In his article Al-Daihani (2018), a study involving undergraduate students at the University of USA found that students commonly use smartphones for academic purposes, like fetching information from a search engine like Google, gain access to libraries, online dictionaries and student portal of their respective university or college. However different researchers try to find out the different information sources that students used to extract information by using smartphones, for example, what percentage of student use Apps to get information, similar like this what percent from Online search engine, articles, blogs, E-library, etc. Many students use it to connect with social media applications and websites to interact with authors to validate the precision of the given information present in their research (Safdar et al., 2020). Also, the increasing usage by medical students and staff have been benefited from fast and easy access to the internet, high-speed surfing experiences gives easy access to medical teaching and learning resources like e-books and textbooks help so much in the learning activity. However, there are some barriers and obstacles in getting knowledge online through smartphones, such as lack of time and screen size, lack of awareness, lack of knowledge, absence of training and deficiency of experience were major barriers faced by students (Abbas and Sagsan, 2019). Some research studies show the effect of smartphones on academic features such as grade point average (GPA) on the major college or university level students. In a study Al-Daihani (2018) investigated the relationship between mobile 
social media consumption and academic performances. The results of this research show that heavy social media mobile consumption is positively related or linked to dropping their GPA.

In the study, Alfawareh and Jusoh (2014), found that almost every student owns a smartphone at their college level, and most of them didn't own it for learning and teaching purposes, but indirectly their smartphones turned into a directed to a beneficial and useful purpose. Also, many studies show that the excess usage of smartphones by students in the classroom during lectures will disconnect students from learning in the classrooms which results in a negative effect on the academic performance of students (Abbas, 2014). The instructor remained concerned that such connections to the social world will lead to disconnect students from learning. Both theoretical and observed evidence supports this concern, signifying that students possibly divert their focus and attention in ways that result in them to slip important details presented during class, a consequence that could have possibly destructive effects on their accomplishment (Chen et al., 2013). In a study published, an interesting experiment has conducted on the two groups of university students. One group has access to smartphones in the classroom during lectures and another group that doesn't have smartphones with themselves during lectures. The aim is to find the connection between smartphones and the attention span of the students during the classroom in both of the groups. The group who are allowed to have a smartphone with themselves receives notification continuously and distracted throughout the class period and their attention period much smaller than the other group without approach to smartphones(Ahmed et al., 2020). The study concluded that the performance of students can be improved by limiting the use of smartphone devices during lectures. Another researcher monitors the student's smartphone usage time on using social media and for the educational learning process, which affects their academic performance in their education carrier in university life (Giunchiglia et al., 2018).

Another study conducted in America that the students who use lesser smartphones tend to achieve higher grade performance than those who use their smartphones for a limited time. Similarly, a researcher demonstrates the inverse relationship between smartphone usage and academic performances among the students in universities (Junco, 2012). The researcher conducted a study on the effects of smartphones on students in India. The author has focused on the difference upon gender to the usage of smartphones and found that females use more smartphones by their male fellow counterparts. Males ignored their work and show poor performance for their extra usage of smartphones due to addiction to it (Campbell, 2006). According to the studies that conducted recently and published in science and Scopus journals, they analyse these studies and they arrived at the result that, overall, in general, there is a positive effect of smartphones on the learning behaviour of university students similarly other studies concluded that smartphones and its applications have positive influences on the student performance in the academic environment and leads to greater results. Although some fewer studies also reveal that, there are some negative effects of smartphones on the students' performance in the university as discussed earlier in the previous studies. So there are double effects of smartphones on the students' performance and studies conclude that a higher level of smartphone addiction in the students may lead to often bad results (Ahmed et al., 2020).

Studies stated that smartphones despite used for communication, gaining knowledge and for the learning process, they had several drawbacks on the peoples especially student's life, such as wastage of time and money, gossiping on useless topics, etc. Researcher James has studied that, students use two hours on their smartphones on average daily, and also 
reveals that smartphone usage is dependency forming, habitual and compulsive and they concluded that it is a non-drug addiction of the 21 century. The normal common observation is that smartphone usage has reached to such a maximum level where people start neglecting their main prioritized works and affects their daily work routine (Nayak, 2018). Some studies found that the use of smartphones and the internet has performed a remarkable role in the distant learning program at the University of Ghana in their academic activities. However, another study also reveals that there is a negative effect on distant learning on the student of universities which included, call interruption during lectures, phone hanging issues due to a low internet connection and small screen size, which made smartphones inconvenient for learning as compared to laptops. By taking the phenomenological method, the researcher directed the study on the motives of why students use smartphones at university. The results express that smartphone usage is to influence the knowledge status form their family, peers, and community and it also reveals that smartphone adoption is a cultural concern and also study shows that smartphones owned as a status symbol that signal affiliation and enhance the mobile users (Lo et al., 2016).

According to the studies revealed by the researcher, it is found that despite the benefits and supporting features of smartphones in the learning process, students mostly used smartphones for using the social media tools and applications like Facebook, Twitter, and Instagram for socializing with their friends and family rather using it for educational purpose. Due to excessive use of smartphone socializing, it negatively affected the education and learning process of students by receiving continuous notifications from different sources. There are several other studies conducted on the behaviour of smartphones on the students in the classrooms, which reveals that mostly student uses their smartphones devices within the classrooms during the lectures which distract their attention from the class learning and most of the time they don't even know the contents of the lecture delivered by the lecturer. And this research based on both theoretical and empirical evidence reveals that using smartphones during lectures by students split or divert their attention which will cause them to miss important points and keynotes details presented during class will result in negatively affecting academic performance achievements (Lee, 2014). Smartphone devices are very common and popular among college students in the US (United States). A high percentage of undergraduate student's own smartphones in the US as relative to same-aged non-students. Junco reported that almost every college student sent on average 97 text messages daily, with 71 of those messages sent while doing some work or assignment. The study by Burns found that $53 \%$ of students reported text messaging or SMS during class (Junco, 2012).

In the study reported, excessively usage of the smartphone was related to college failure and also leads to other undesirable behaviours such as alcohol and smoking usage. Modern smartphones enable access to a variety of social and electronic media to students at almost anywhere anytime. This will cause a huge loss of precious time and money resources by these students. Popular activities like playing games, watching series, surfing the internet, and roaming around in social media sites will be accomplished by most smartphone users especially students because they are the main market segment and huge consumers of smartphones. All these activities take so much time from these students which causes them to distract their attention and focus from their studies(Faculty of Modern Language and Communication Universiti Putra Malaysia 43400 UPM Serdang Selangor Darul Ehsan, Malaysia and Mothar, 2013). The researcher has connected all these activities, independent of smartphone usage to academic performance. Also, heavy mobile gaming for long durations has been associated with lower academic performance and lower GPA's. The same studies 
also reveal that there is a negative relationship between smartphone social media networking with academic performances. This relationship has found in the maximum population across the world, including North America, Asia, Europe (Hossain, 2019).

Recently a study regarding multitasking reveals that during lectures in the classroom, when students use smartphones, they have been performing multitasking and researcher measured the effect of multitasking on academic performance, they investigate these concerns and find that many students regularly report using different electronic media including smartphones while in-class lectures, reading at home, and completing assignments or homework, and conclude that there is a negative relationship among multitasking and academic performance (Hossain, 2019). In 2011, A researcher Soloway reveals in his study that student's achievements and output increase when they use electronic mobile learning devices, including smartphones, laptops, tablets, etc., during learning time. Because their time spent on learning procedures will decrease and task completion time will increase when they have a smartphone device. In a study Nayak (2018) found that many students download class material contents and reading by E-book to improve learning. Another study reveals that some students use a new way of learning instead of using internet and E-book, but they fully utilize mobile learning applications such as emails, voicemails, camera, voice recorder, google drive, GPS and so forth to create, upload, download and to share their academic resources and content with their friends and teachers. This is positively associated with the sophisticated rate of smartphone ownership among higher education students( $\mathrm{Ng}$ et al., 2017).

In modern years, more research studies were conceded on smartphone usage concerning academic performance. For instance, Jacobsen and Forste $(2011$, p. 4) in their study establish a negative association between texting, calling, and self-reported grade point average (GPA) between university students in the US (United States). While on another hand, Hong et al (2012) found that texting and calling were positively associated with a self-reported measure of academic difficulty among a sample of female Taiwanese university students. However, in another research, Lepp et al (2015) reported that students who used the smartphone more daily were likely to have a lower GPA than students who used it less. Based on their conclusions on a sample of 536 undergraduates from 82 self-reported majors at a large public university, the researchers recommended a vital need to sensitize students and educators about the potential academic risks associated with high smartphone use ( $\mathrm{Ng}$ et al., 2017). Additional studies were conducted to explore the reasons behind a negative relationship between electro media use and academic performance, multitasking has appeared as a possible explanation. As smartphone use is not only restricted to texting and calling but Internet use, email, and social networking sites such as Facebook, it can potentially increase multitasking and task switching during academic activities, this will eventually lead to a drop in academic performance (Ng et al., 2017).

Regardless of the prevalent smartphone usage among tertiary level students, the degree to which this technology has donated into their academic achievement is still unconvincing. Smartphone functions are no longer limited to only texting and calling; instead, a wide collection of activities needs to be considered. Based on previous existing literature, this experimental study was carried out to determine the degree of smartphone use in terms of learning by students at one Malaysian university and to examine the relationship between smartphone use for related learning activities and student's academic performance. The conclusions of the present study may help articulate a theoretical basis for further research (Ng et al., 2017). Bumhold describes the educational purpose of smartphones especially 
mobile android applications by undergraduate university students in the information technology department. They found that student's most frequently used applications were search engines and social media communication as a category wise (Hossain and Ahmed, 2016).

Mobile learning is proposed as an improvement in E-learning as an independent part of e-learning however it is difficult to trace when the concept of e-learning exactly appears. Several limitations of mobile learning also discussed by some researchers including physical, psychological, and technical ones such as small screen size, limited adequate memory as well as compatibility issues (Wai et al., 2018). Usage of the online library through smartphones by students explored and they found that students access information on library opening hours. And Students preferred to access the library through their smartphones instead of laptops or desktop computers because they are portable and easy to carry here and there (Vassilakaki et al., 2016). Most recently, Dresselhaus surveyed students on their use of smartphone devices for academic purposes. They stated that 54 percent of undergraduate students at Utah State University use smartphones for academic purposes. Of those, 70.8 percent of students stated that they owned a handheld device. To appraise the use of handheld devices to access academic information, the authors provided results based on the students' respective colleges, more than half of the students in the colleges of engineering and business stated using smartphones for academic work. While related, the data for this study were collected in 2010 and maybe outdated (Bomhold, 2013). Researcher Hahn conducted an interesting case study in which smartphone devices used to locate the materials in the book stacks of libraries. He discussed how location-based service is important in large shelf book libraries and he successfully launched a feature of updated technology-oriented smartphones to locate the books (Koops, 1985)

Worldwide, smartphones use amongst every age level of students and scholars has greater than before enormously over the last two years. Higher learning institutions need to improve comprehensive approaches to influence students' smartphone use to create a more independent learning environment. Up to date, several studies have been directed to explore the consumption of smartphone devices themselves. For most of the research reporting on the benefits and limitations of the smartphone, there was very slight practical evidence to support their claims. While there is some indication concerning student's use of smartphones in higher education, there is little research on how they have used smartphones to support learning activities and how this relates to academic performance. This study considered the quantity of time tertiary level students used smartphones in different learning activities and discovered how it influenced their academic performance. Understanding the stated relationship may give insights as to whether smartphone usage has indeed contributed to increasing students' learning opportunities or likewise affected their academic performance negatively ( $\mathrm{Ng}$ et al., 2017). The use of smartphones is popular among professors and staff members who are linked with education spreading around the students. They report that they use this device to communicate with colleagues and members to brainstorm and discussing the problem they face in their academic activities. There are significant relationships found between smartphones and effective learning mechanisms among students as well as teachers and professors (Alfawareh and Jusoh, 2017).

Studies show some results that, students who used excessive smartphones likely to indulge in overusing of internet and likely to access social networks and they spend so much time chatting with their friends. The study suggests that students can increase their academic performance level by viewing online course resources and video concepts related to their 
projects and assignments as some may have an advantage over others in completing the work. Smartphone facilitates its users in learning by online and offline either, offline access enables the users by providing them with the features of smartphones in learning materials such as PDF, PowerPoint, word, excel and animations, etc. (Darko-Adjei, n.d.). The researcher investigated several other factors regarding this study and concludes that most students waste their time on useless activities by using their smartphones which includes heavy gaming, socializing, watching movies, and several other tasks they do during their whole day. All these activities associated with negative impacts on academic performance and leads to the failure of students in their education carrier (Lepp et al., 2015). Although there are so many positive aspects of smartphones are found, but on another hand, smartphone use perceived as favourable before the study but later students reveal that smartphones viewed as detrimental to their educational goals in the end. It's all about the attitude-behaviour that influences the student's objectives and moto to get benefit from these electronic devices or being manipulated by these technologies (Ng et al., 2017).

Thus, founded on the previously available literature, it is concluded that there are questionable outcomes concerning smartphone use and student academic performance in universities, therefore there is a robust necessity to examine this relationship with more variables and with a larger scope. Hence, keeping a view of these effects of the smartphone on student academic performance in universities, this study is an attempt to determine a relationship between student academic performance in universities and smartphone usage in Pakistan. According to Ahmed et al, recent statistics exhibited that $60 \%$ of the Pakistani population consists of youth who are major users of smartphones, therefor this study primarily focuses on university students. In this situation, the importance of the assumed study has more practical associations from the perspective of student academic performance in Pakistani universities(Ahmed et al., 2020).

The purpose of this research is to identify that students are using smartphones for different purposes related to learning activities. Their usage will be effecting the behaviour and dynamics or not. Students' academic performance is affected whether positively or negatively by the usage of smartphones. Or the students waste their precious time using social media etc. other than studies. So we will check the effects of smartphones on different variables such as Academic performances, Learning behaviour, Attention period time.

\section{Hypotheses}

H1: Usage of smartphones has a Positive relationship with the learning behaviour

H1: Usage of smartphones has a positive relationship with the academic performance 
Figure 1: Research Model

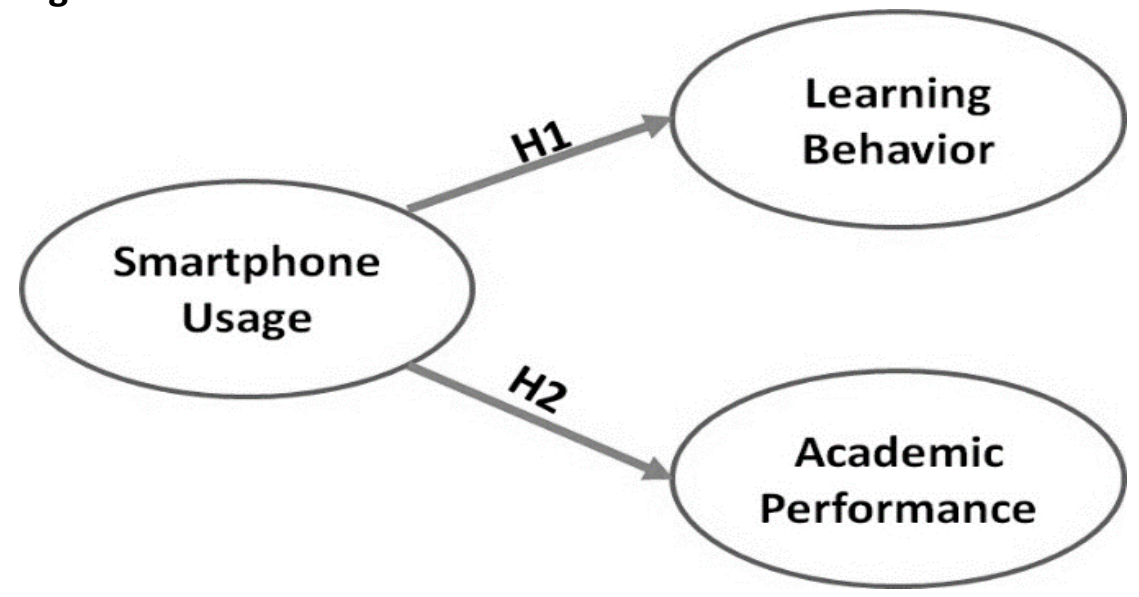

\section{Research Methodology}

Target Population and Sampling Procedure

The target population chosen for this study is based on a criterion that including only all of those students studying in the Universities in Islamabad, Pakistan and are using smartphones in their daily work routine to indulge in their learning activities and into the learning process in the undergraduate or postgraduate programs in University in Islamabad, Pakistan. We use these targeted populations and samples because our study is based on these samples who use smartphones. We conducted this research on March 10, 2020, and data were collected between February and March 2020. Since it was very difficult for the researcher to collect data from all the population, for such situation, Abbas (2019, 2020a) recommended to follow a non-probability convenience sampling technique. The researcher selected those respondents who were using smartphones, and they were well aware of the functionalities of smartphones from the main capital city Islamabad. Initially, 170 questionnaires were floated to the respondents in which 150 responses were found corrected and completed. However, 20 responses were found incorrect or incomplete. The sample size we use is 150 respondents comprising of both $60 \%$ male and $40 \%$ female students who were conveniently sampled from a University located in Rawalpindi/Islamabad, Pakistan.

The researcher collected data by using Google Drive form by sharing online form weblink through electronic means like email and social platforms to online members, and also by distributing the form manually around the students in the University by requesting them to fill their concerns regarding the impact on a five-point Likert scale. This research is developed with a quantitative approach and employed a correlational research design. It consists of several demographic features including age, gender, qualification, semester, etc., and to be focused to discover the relationship among the usage of smartphones and university students' performance in Rawalpindi/Islamabad, Pakistan.

\section{The Measurement Instrument}

In this study, we used questionnaires and distributed among the students of the University voluntarily who are enrolled in undergraduate and postgraduate programs and used or using Smartphones in their daily life routine for learning purposes. All of them give their feedback by volunteering without putting any pressure. The items for questionnaire were imported from Han and Yi's (2019) article. After importing, the questionnaire was modified completely according to the need and requirements of our research objectives. We used multiple answer options by using a five-point Likert scale. The questionnaire was 
consisting of two parts. The first part consists of demographic information regarding the sample and participant's characteristics who participate in the survey and the second part includes the questions regarding our study and findings. Abbas and Sağsan (2019); Imran and Abbas (2020) also followed similar approach in their research.

\section{Sample Size and Sampling Technique:}

We employed a non-probability sampling technique. We selected those respondents who were using smartphones, and they were well aware of the functionalities of smartphones. Initially, 200 questionnaires were floated to the respondents out of which 170 were received and 150 responses were found corrected and completed. The survey was administered among $65 \%$ of males and $35 \%$ of females from a total of 150 students' samples.

Data Analyses and Results:

A general survey was conducted among the students of the university including different semesters and different demographics features. First, we discuss the different demographic features upon which we need to analyse data. The details are given below. The total response we get is 150 in number from both genders, from which approximately 97 are Male students and 53 are female students. In which there are different age groups of people total 150 participate in the study and most of them are between 15 to 35 of age group. A summary show that approximately $40 \%$ respondents was in between $25-35$. There is a different level of education from students participate and most of them that $50 \%$ are in Bachelors and $44 \%$ are doing Masters in different disciplines. As we show that students participated in the study from different disciplines. Most of the students are from Management Sciences which shows 35\% and the Computer science department which is $31 \%$ population. The rest of them are from several other departments including Engineering, Social science, etc. Another demographic we used to differentiate data by semester. And statistics show that most of the students are in the $3^{\text {rd }}$-4rth semester of their degree.

After getting all the required data about demographic features, we were able to analyse the data from different angles. We observe that most of the students who participate in the study were enrolled in Bachelors and Master's program from $3^{\text {rd }}-4^{\text {th }}$ semester. Most of them are males consisting of the age group between 25 to 30. Data shows that most of the students are from the Management sciences department. After that, we will analyse and understand the pattern of different questions that we ask from the different respondents. To find some usage behaviour and purpose of smartphone usage in the students, we use certain questions to analyse the behaviour. These responses to these questions were direct get from the respondents. The questions are a total of 18 in numbers and aim to find the usage behaviour and different usage pattern among different people. As we know that different age groups of people and people relating to different fields of work may have different priorities and requirements on which they use smartphones differently. For this purpose, we differentiate the results and findings into different demographic perspectives. For example, what percentage of male students have responded to what preferences on the five-point Likert scale.

In response to the question asked from participants about the overall usefulness and efficiency of smartphones in the learning process, 74 percent of male students (120) responded strongly agreed and 26 percent of females (30) have agreed 24 percent strongly agree regarding the concern. As it can be seen from the table that 53 percent of student have agreed and on the research, the question stated that does smartphone use in classroom assist them in learning, this includes both male and female from every age group and different 
departments overall findings. Contrary to this question, the other question that asked from the respondents that, is the smartphone interfere in their learning during the lecture in the classroom. The response we get from them is 21 percent are strongly agreed on the question and approximately 30 percent agreed. And a large number of people just show either agree or disagree option which is a 33.7 percent in ratio.

Table 1. Demographics characteristics of Respondents

\begin{tabular}{llll}
\hline Particulars & Details & Participants & Percentage \\
\hline Gender & Male & 98 & $65.3 \%$ \\
Age & Female & 52 & $34.7 \%$ \\
& $15-20$ & 24 & $16 \%$ \\
Education & $20-25$ & 67 & $44.7 \%$ \\
& $25-35$ & 59 & $39.3 \%$ \\
& $35+$ & 0 & $1 \%$ \\
& College Student & 3 & $2 \%$ \\
Discipline & Bachelors & 76 & 50.7 \\
& Masters & 66 & $44 \%$ \\
& PhD & 2 & $1.3 \%$ \\
& Management Science & 43 & $35.5 \%$ \\
Semester & Computer Science & 38 & $31.4 \%$ \\
& Engineering & 11 & $9.1 \%$ \\
& Social sciences & 4 & $2 \%$ \\
& 1 st $-2^{\text {nd }}$ & 21 & $17.4 \%$ \\
& $3 r d-4^{\text {th }}$ & 73 & $60.3 \%$ \\
& 5 th $-6^{\text {th }}$ & 21 & $17.4 \%$ \\
& $7+$ & 4 & $3.3 \%$ \\
\hline
\end{tabular}


INTERNATIONAL JOURNAL OF ACADEMIC RESEARCH IN BUSINESS AND SOCIAL SCIENCES Vol. 11, No. 2, 2021, E-ISSN: 2222-6990 @ 2021 HRMARS

Table2: Relationship between Smartphones usage and Students' learning Behaviour and Academic Performance.

\begin{tabular}{|c|c|c|c|c|c|c|c|}
\hline Construct & $\begin{array}{l}\text { Strong } \\
\text { ly } \\
\text { Disagr } \\
\text { ee }\end{array}$ & $\begin{array}{l}\text { Disagr } \\
\text { ee }\end{array}$ & $\begin{array}{l}\text { Undecid } \\
\text { ed }\end{array}$ & $\begin{array}{l}\text { Agre } \\
\text { e }\end{array}$ & $\begin{array}{l}\text { Strong } \\
\text { ly } \\
\text { Agree }\end{array}$ & $\begin{array}{l}\text { Me } \\
\text { an }\end{array}$ & $\begin{array}{l}\text { Standar } \\
\text { d } \\
\text { Deviati } \\
\text { on }\end{array}$ \\
\hline \multirow{2}{*}{$\begin{array}{l}\text { With a smartphone, I use to search for } \\
\text { information. }\end{array}$} & 2 & 4 & 13 & 59 & 72 & 4.3 & 0.414 \\
\hline & $1.3 \%$ & $2.7 \%$ & $8.7 \%$ & \begin{tabular}{|l|}
39.3 \\
$\%$
\end{tabular} & $48 \%$ & & \\
\hline \multirow[t]{2}{*}{ With a smartphone, I use to take tests. } & 16 & 52 & 37 & 30 & 15 & 2.84 & 1.164 \\
\hline & $10.7 \%$ & $34.7 \%$ & $24.7 \%$ & $20 \%$ & $10 \%$ & & \\
\hline \multirow{2}{*}{$\begin{array}{l}\text { With a smartphone, I use to work on } \\
\text { assignments. }\end{array}$} & 9 & 14 & 31 & 65 & 31 & 3.63 & 1.095 \\
\hline & $6 \%$ & $9.3 \%$ & $20.7 \%$ & $\begin{array}{l}43.3 \\
\% \\
\end{array}$ & $20.7 \%$ & & \\
\hline \multirow{2}{*}{$\begin{array}{l}\text { With a smartphone, I use to submit } \\
\text { assignments. }\end{array}$} & 11 & 26 & 24 & 55 & 34 & 3.5 & 1.224 \\
\hline & $7.3 \%$ & $17.3 \%$ & $16 \%$ & $\begin{array}{l}36.7 \\
\%\end{array}$ & $22.7 \%$ & & \\
\hline \multirow{2}{*}{$\begin{array}{l}\text { With a smartphone, I use to work on } \\
\text { presentations. }\end{array}$} & 13 & 25 & 28 & 54 & 30 & 3.42 & 1.227 \\
\hline & $8.7 \%$ & $16.7 \%$ & $18.7 \%$ & $36 \%$ & $20 \%$ & & \\
\hline \multirow{2}{*}{$\begin{array}{l}\text { With a smartphone, I use to access an E- } \\
\text { library. }\end{array}$} & 42 & 56 & 15 & 17 & 20 & 2.44 & 1.358 \\
\hline & $28 \%$ & $37.3 \%$ & $10 \%$ & $\begin{array}{l}11.3 \\
\% \\
\end{array}$ & $13.3 \%$ & & \\
\hline \multirow{2}{*}{$\begin{array}{l}\text { With a smartphone, I use to register for } \\
\text { courses. }\end{array}$} & 10 & 26 & 19 & 50 & 45 & 3.62 & 1.261 \\
\hline & $6.7 \%$ & $17.3 \%$ & $12.7 \%$ & $\begin{array}{l}33.3 \\
\%\end{array}$ & $30 \%$ & & \\
\hline \multirow{2}{*}{$\begin{array}{l}\text { With a smartphone, I use to navigate } \\
\text { course websites. }\end{array}$} & 13 & 29 & 27 & 54 & 27 & 3.35 & 1.226 \\
\hline & $8.7 \%$ & $19.3 \%$ & $18 \%$ & $36 \%$ & $18 \%$ & & \\
\hline \multirow{2}{*}{$\begin{array}{l}\text { With a smartphone, I use to read course } \\
\text { materials. }\end{array}$} & 6 & 9 & 16 & 70 & 49 & 3.98 & 1.019 \\
\hline & $4 \%$ & $6 \%$ & $10.7 \%$ & $46 \%$ & $32.7 \%$ & & \\
\hline \multirow{2}{*}{$\begin{array}{l}\text { With a smartphone, My Academic } \\
\text { performance improved. }\end{array}$} & 8 & 4 & 21 & 54 & 63 & 4.06 & 1.072 \\
\hline & $5.3 \%$ & $2.7 \%$ & $14 \%$ & $36 \%$ & $42 \%$ & & \\
\hline \multirow{2}{*}{$\begin{array}{l}\text { With a smartphone, I used to record } \\
\text { lectures. }\end{array}$} & 14 & 31 & 32 & 48 & 25 & 3.26 & 1.228 \\
\hline & $19.3 \%$ & $20.7 \%$ & $21.3 \%$ & 32 & $16.7 \%$ & & \\
\hline Construct & SD & $D$ & $\begin{array}{l}\text { Undecid } \\
\text { ed }\end{array}$ & $A$ & SA & $\begin{array}{l}\text { Mea } \\
\mathrm{n}\end{array}$ & S.D \\
\hline \multirow{2}{*}{$\begin{array}{l}\text { With a smartphone, I use to watch course- } \\
\text { related video files. }\end{array}$} & 7 & 39 & 35 & 42 & 27 & 3.28 & 1.172 \\
\hline & $4.7 \%$ & $26 \%$ & $23.3 \%$ & $28 \%$ & $18 \%$ & & \\
\hline \multirow{2}{*}{$\begin{array}{l}\text { With a smartphone, I used to share } \\
\text { course-related information with friends. }\end{array}$} & 6 & 16 & 20 & 64 & 44 & 3.82 & 1.091 \\
\hline & $4 \%$ & $10.7 \%$ & $13.3 \%$ & $\begin{array}{l}42.7 \\
\% \\
\end{array}$ & $29.3 \%$ & & \\
\hline \multirow{3}{*}{$\begin{array}{l}\text { With a smartphone, I use to talk about } \\
\text { course work with my friends. }\end{array}$} & 5 & 24 & 14 & 61 & 46 & 3.79 & 1.142 \\
\hline & $3.3 \%$ & $16 \%$ & $9.3 \%$ & $\begin{array}{l}40.7 \\
\%\end{array}$ & $30.7 \%$ & & \\
\hline & 9 & 39 & 27 & 43 & 32 & 3.33 & 1.240 \\
\hline
\end{tabular}




\begin{tabular}{|c|c|c|c|c|c|c|c|}
\hline $\begin{array}{l}\text { With a smartphone, I use to ask } \\
\text { instructors course-related questions. }\end{array}$ & $6 \%$ & $26 \%$ & $18 \%$ & $\begin{array}{l}28.7 \\
\%\end{array}$ & $21.3 \%$ & & \\
\hline \multirow{2}{*}{$\begin{array}{l}\text { Using a smartphone helps me to study } \\
\text { more efficiently }\end{array}$} & 6 & 5 & 15 & 69 & 55 & 4.08 & 0.979 \\
\hline & $4 \%$ & $3.3 \%$ & $10 \%$ & $46 \%$ & $36.7 \%$ & & \\
\hline \multirow{2}{*}{$\begin{array}{l}\text { Using a smartphone improves my } \\
\text { performance in studying. }\end{array}$} & 9 & 3 & 16 & 58 & 64 & 4.1 & 1.072 \\
\hline & $6 \%$ & $2 \%$ & $10.7 \%$ & $\begin{array}{l}38.7 \\
\%\end{array}$ & $42.7 \%$ & & \\
\hline \multirow{2}{*}{$\begin{array}{l}\text { Using a smartphone increases my course } \\
\text { work productivity. }\end{array}$} & 7 & 5 & 18 & 67 & 53 & 4.02 & 1.016 \\
\hline & $4.7 \%$ & $3.3 \%$ & $12 \%$ & $\begin{array}{l}44.7 \\
\%\end{array}$ & $35.3 \%$ & & \\
\hline \multirow{2}{*}{$\begin{array}{l}\text { Using a smartphone enhances my study } \\
\text { effectiveness. }\end{array}$} & 10 & 5 & 19 & 62 & 54 & 3.96 & 1.107 \\
\hline & $6.7 \%$ & $3.3 \%$ & $12.7 \%$ & $\begin{array}{l}41.3 \\
\%\end{array}$ & $36 \%$ & & \\
\hline \multirow{2}{*}{$\begin{array}{l}\text { Students use dictionary/ } \\
\text { thesaurus/calculator of mobile phone in } \\
\text { classes }\end{array}$} & 5 & 5 & 7 & 40 & 47 & 4.12 & 1.042 \\
\hline & $4.8 \%$ & $4.8 \%$ & $6.7 \%$ & $\begin{array}{l}38.5 \\
\%\end{array}$ & $45.2 \%$ & & \\
\hline \multirow{2}{*}{$\begin{array}{l}\text { Using a smartphone makes it easier to } \\
\text { complete my course work. }\end{array}$} & 8 & 9 & 8 & 69 & 56 & 4.04 & 1.073 \\
\hline & $5.3 \%$ & $6 \%$ & $5.3 \%$ & $46 \%$ & $37.3 \%$ & & \\
\hline \multirow{2}{*}{$\begin{array}{l}\text { Using a smartphone gives me greater } \\
\text { control over my studies. }\end{array}$} & 10 & 9 & 21 & 58 & 52 & 3.88 & 1.150 \\
\hline & $6.7 \%$ & $6 \%$ & $14 \%$ & $\begin{array}{l}38.7 \\
\%\end{array}$ & $34.7 \%$ & & \\
\hline \multirow{2}{*}{$\begin{array}{l}\text { Does the use of smartphones during your } \\
\text { study time distract you? }\end{array}$} & 3 & 34 & 34 & 16 & 17 & 3.30 & 1.186 \\
\hline & $2.9 \%$ & $32.7 \%$ & $32.7 \%$ & $\begin{array}{l}15.4 \\
\%\end{array}$ & $16.3 \%$ & & \\
\hline \multirow{2}{*}{$\begin{array}{l}\text { Using a smartphone in class assist in your } \\
\text { learning? }\end{array}$} & 3 & 7 & 13 & 56 & 25 & 3.94 & 0.995 \\
\hline & $2.9 \%$ & $6.7 \%$ & $12.5 \%$ & $\begin{array}{l}53.8 \\
\%\end{array}$ & $24 \%$ & & \\
\hline \multirow{2}{*}{$\begin{array}{l}\text { Using a smartphone in class interferes } \\
\text { with your learning? }\end{array}$} & 3 & 13 & 35 & 31 & 22 & 3.45 & 1.138 \\
\hline & $2.9 \%$ & $12.5 \%$ & $33.7 \%$ & $\begin{array}{l}29.8 \\
\%\end{array}$ & $21.2 \%$ & & \\
\hline \multirow{2}{*}{$\begin{array}{l}\text { Do the calls/messages received just before } \\
\text { class impact on your ability to concentrate }\end{array}$} & 6 & 15 & 22 & 43 & 18 & 3.25 & 1.210 \\
\hline & $5.8 \%$ & $14.4 \%$ & $21.2 \%$ & $\begin{array}{l}41.3 \\
\%\end{array}$ & $17.3 \%$ & & \\
\hline \multirow{2}{*}{$\begin{array}{l}\text { Overall, I find a smartphone useful in my } \\
\text { studies. }\end{array}$} & 5 & 5 & 10 & 34 & 93 & 4.36 & 1.006 \\
\hline & $3.3 \%$ & $3.3 \%$ & $6.6 \%$ & $\begin{array}{l}22.7 \\
\%\end{array}$ & $62 \%$ & & \\
\hline
\end{tabular}

When we ask the respondents about smartphone use regarding the information searching. 48 percent of people respond Strongly Agreed regarding the question and approximately 40 percent respond Agreed. Overall responses of students shown in the graph which include the total agreed responses, total disagreed responses and the response of people who neither agree nor disagree.

In response to the question of "using a smartphone to read course material", 46 percent of sample size have responded to Agree and 32 percent of people chosen Strongly Agree. It means that most of the students using the smartphone. These findings and results 
show that students in Pakistan often used their smartphones for searching for their course contents and academic literature. All of these results show that the smartphone is positively correlated with good academic performance and better learning behaviour to learn new things in a new way. The first question on table 2 ask that "Are students use smartphones for searching information for their academic purpose?" The findings reported that (48\%) of the respondents have strongly agreed and (39.3\%) respondents have Agreed that Smartphones help students to search for information from anywhere, anytime with the tips of their fingers. Several other researchers supported this study in their findings. When we find the mean of this question, it becomes (4.3). When we talk about the second question that we asked from the members is "With a smartphone, I use to take tests." At this point, the response rate is quite different, like there is a (34.7\%) Disagreed and only (20\%) Agreed upon this. This means that people usually do not use smartphones to take tests. So this means that smartphone is used other than this reason. When we ask the respondents about the work on assignments with the help of smartphones, the respondent responds (43.3\%) on Agreed and $(20.7 \%)$ on Strongly Agreed. These results show that smartphone usage is different among different activities and different people use this device for different purposes.

The most important question that we had surveyed is "With Smartphones, My Academic performance is improved". The response rate is quite amazing and helps us to conclude and find the results. The respondents had chosen to (42\%) Strongly Agreed and (36\%) has chosen Agreed which aggregately makes (78\%) response rate on Agreed. The other important question we ask from the respondent is "Students use dictionary/ thesaurus/calculator of mobile phone in classes". Table 2 found that $(45 \%)$ of the students have Strongly Agreed and (38\%) have agreed that they used a dictionary, calculator or other tools by using smartphones in their academic activities. According to data retrieved from the questionnaire, the learning behaviour of students shows that most of the students do make assignments and read their course-related material and online videos relating to their academic contents. Most of the students use a calculator and dictionary to support or assist their learning. Many of them had several learning tools and applications installed on their smartphones which they efficiently utilize to increase their knowledge and information. We calculate mean and standard deviation against each question that asked from the respondents, they show different values that when we put them together, depicts the results of the study. Results show that many students approximately 75 percent agree to the effectiveness of smartphones on the studies and performance and many of them used smartphones to perform different tasks and activities to increase their learning effectiveness by using different applications and internet sources to support their academic content.

\section{Discussing the Results}

Students from universities around the globe use smartphones, these are the maximum users who are aged between 20-30, most of them are students and they are the early adopter of these technological devices in developing countries like South Asia and its nearby places. The findings conclude that there are both positive and negative impacts of the smartphone on academic performance and learning attitude and behaviour but the point here is that positive impacts are higher than negative.

Positive Impact of Smartphones:

- Smartphones help the student to access information at any time anywhere around the globe with the tips of their fingers. 
- Smartphone tools for academic learning like Dictionary, thesaurus, and calculator helps the students to learn efficiently and effectively.

- Findings conclude that the usage of smartphones in students helps to improve their academic performances in their education learning system.

- Smartphone helps students to gain greater control over their studies and learning processes.

Negative Impact of Smartphones:

- Smartphones may cause a decrease in attention time-span of students during the lecture in classrooms due to the diverting of attention by notifications received from smartphones.

- Smartphones interfere in the classroom during lectures given by professors and may cause to divert attention from the lecture and missed the important information presented in the class.

- Mostly students use these technological devices for their entertainment purposes and waste their precious time in these socializing and movies watching activities. This may cause them to waste their precious time.

\section{Results}

Results and findings show that about 80 percent of students agree that, they used smartphones for searching information and almost 70 percent of the students strongly agree to the point that smartphones help students to improve their academic performances and they efficiently complete their projects and assignments. On the other side, 40 percent agree that smartphones disrupt their learning process during the lecture in the class. Many students agree on the usage of the dictionary, calculator and other tools during their study hours. Many of them strongly agree that by the use of the smartphone, they have greater control over their studies and make it easier for them to complete their tasks and assignments.

However, differences are found with related to gender in usage consumption, showing that male students use smartphones more often and widely for different purposes as compared to female students, female students mostly use their smartphones to use social media sites, blogging and keep updating themselves by fashion trends. Also, some differences are found in the response trends among students based on their age and semester wise. Age group between 25-30 are mostly agreed to the fact that they efficiently use their smartphone in their learning activities and they found it helpful in learning new programs and concepts by using Wikipedia, YouTube, Google, etc.

The current research provides valuable insights to the parents, academic staff, and all persons having stake in students' learning behaviour and academic performance. It also sheds light on the positive and negative aspects of smartphones usage by students. It is recommended that extensive use of smartphone by students should be discouraged by parents and teachers since it can negatively affect students' learning attitude.

\section{Limitations}

As our study is concerned about students of the university who used smartphones in their academic learning programs to support their learning activities, and the point of concern here is that students are located in Islamabad and Rawalpindi. So this is the one limitation of the study that we only focused on one city because we are unable to spread our study to other cities of Pakistan due to shortage of time and limited resources, so in the future, whenever some researchers further extend the study, these concerns should be noted. 
This research is quantitative-based, so this will be qualitative on the next approach. Also, our concern is focusing on the effects of smartphones on academic performance and learning behaviour. Several other possible variables should be tested in the future with the effects of smartphones.

\section{Conclusions}

Articles on Smartphones and its effects on the society and people are published by many researchers despite very little findings are on the effects on learning behaviour and academic performances. This unique study carefully examined and analysed the impact of Smartphones on the students' performance and their lifestyle learning behaviour. This study discovers both the positive and negative results of this modern technological advancements. The research study concludes that most of the students use smartphones to search for information and data, and most of the students use the dictionary, thesaurus, and several other tools like calculators and learning applications to learn new information contents. These findings highlight the positive aspect of the usage of smartphones and the learning behaviour of students has changed and improved. Appropriate recommendations were made regarding this like, it's better to use a smartphone with the purposeful intentions and strong motivation to use it positively for better results.

\section{References}

Abbas, J. (2014). Impact of Academic Policies and Profiles on Performance and Survival of Business Graduates [Institute of Business \& Management, University of Engineering \& Technology].https://www.researchgate.net/publication/321255370_Impact_of_Acade mic_Policies_and_Profiles_on_Performance_and_Survival_of_Business_Graduates?_s $\mathrm{g}=x g Q L 0 o p 8 Z X 0 v O V X L 76 R 9 A 40 B i B y M s O E j f a w-L p H O q c Q Q 8 \mathrm{CH}-$ bqVsPCFw68awuwy8iLIH6VJ8vJAMtMewMJWhXRw0wEz1XAIXL3MkIVSs.a9E1LFFNrBFI UvNKTsCLa9HBtuQg7CGTxh57UkEkPO6L1EQjPrsSrdL5fhlQT127g0aglgHjGzql4g42XSnb $4 \mathrm{~g}$

Abbas, J. (2019). Impact of total quality management on corporate sustainability through the mediating effect of knowledge management. Journal of Cleaner Production, 244, 118806. https://doi.org/10.1016/j.jclepro.2019.118806

Abbas, J. (2020a). Impact of total quality management on corporate green performance through the mediating role of corporate social responsibility. Journal of Cleaner Production, 242, 118458. https://doi.org/10.1016/j.jclepro.2019.118458

Abbas, J. (2020b). Service Quality in Higher Education Institutions: Qualitative Evidence from the Students' Perspectives using Maslow's Hierarchy of Needs. International Journal of Quality and Service Sciences, 12(3), 371-384.

Abbas, J. (2020c). HEISQUAL: A modern approach to measure service quality in higher education institutions. Studies in Educational Evaluation, 67, 100933. https://doi.org/10.1016/j.stueduc.2020.100933

Ahmed, R. R., Salman, F., Malik, S. A., Streimikiene, D., Soomro, R. H., \& Pahi, M. H. (2020). Smartphone Use and Academic Performance of University Students: A Mediation and Moderation Analysis. Sustainability, 12(1), 439. https://doi.org/10.3390/su12010439

Ahsan, M. U., Nasir, M., \& Abbas, J. (2020). Examining the Causes of Plastic Bags Usages and Public Perception about its Effects on the Natural Environment. International Journal of Academic Research in Business and Social Sciences, 10(10), 80-96. http://dx.doi.org/10.6007/IJARBSS/v10-i10/7919 
Al-Daihani, S. M. (2018). Smartphone use by students for information seeking. Global Knowledge, Memory and Communication, 67(4/5), 194-208. https://doi.org/10.1108/GKMC-01-2018-0008

Al-Emran, M., Elsherif, H. M., \& Shaalan, K. (2016). Investigating attitudes towards the use of mobile learning in higher education. Computers in Human Behavior, 56, 93-102. https://doi.org/10.1016/j.chb.2015.11.033

Alfawareh, H. M., \& Jusoh, S. (2017). The Use and Effects of Smartphones in Higher Education. International Journal of Interactive Mobile Technologies (IJIM), 11(6), 103. https://doi.org/10.3991/ijim.v11i6.7453

Arif, I., Aslam, W., \& Ali, M. (2016). Students' dependence on smartphones and its effect on purchasing behavior. South Asian Journal of Global Business Research, 5(2), 285-302. https://doi.org/10.1108/SAJGBR-05-2014-0031

Campbell, S. W. (2006). Perceptions of Mobile Phones in College Classrooms: Ringing, Cheating, and Classroom Policies. Communication Education, 55(3), 280-294. https://doi.org/10.1080/03634520600748573

Chen, H., Chen, H., Fulton, C., Gleave, H., Theng, Y.-L., \& Wu, M.-M. (2013). Use of mobile apps in information seeking: An international viewpoint: Use of Mobile Apps in Information Seeking: An International Viewpoint. Proceedings of the American Society for Information Science and Technology, 50(1), 1-4. https://doi.org/10.1002/meet.14505001004

Darko-Adjei, N. (n.d.). THE USE AND EFFECT OF SMARTPHONES IN STUDENTS' LEARNING ACTIVITIES: EVIDENCE FROM THE UNIVERSITY OF GHANA, LEGON. 38.

Faculty of Modern Language and Communication Universiti Putra Malaysia 43400 UPM Serdang Selangor Darul Ehsan, Malaysia, \& Mothar, M. M. (2013). The Importance of Smartphone's Usage Among Malaysian Undergraduates. IOSR Journal Of Humanities And Social Science, 14(3), 112-118. https://doi.org/10.9790/1959-143112118

Giunchiglia, F., Zeni, M., Gobbi, E., Bignotti, E., \& Bison, I. (2018). Mobile social media usage and academic performance. Computers in Human Behavior, 82, 177-185. https://doi.org/10.1016/j.chb.2017.12.041

Habib, M., Abbas, J., \& Noman, R. (2019). Are human capital, intellectual property rights, and research and development expenditures really important for total factor productivity? An empirical analysis. International Journal of Social Economics, 46(6), 756-774. https://doi.org/10.1108/IJSE-09-2018-0472

Han, S., \& Yi, Y. J. (2019). How does the smartphone usage of college students affect academic performance? Journal of Computer Assisted Learning, 35(1), 13-22. https://doi.org/10.1111/jcal.12306

Hong, F.-Y., Chiu, S.-I., \& Huang, D.-H. (2012). A model of the relationship between psychological characteristics, mobile phone addiction and use of mobile phones by Taiwanese university female students. Computers in Human Behavior, 28(6), 21522159. https://doi.org/10.1016/j.chb.2012.06.020

Hossain, M. (2019). Impact of Mobile Phone Usage on Academic Performance. 17.

Hossain, Md. E., \& Ahmed, S. M. Z. (2016). Academic use of smartphones by university students: A developing country perspective. The Electronic Library, 34(4), 651-665. https://doi.org/10.1108/EL-07-2015-0112

Imran, M., \& Abbas, J. (2020). The Role Of Strategic Orientation In Export Performance Of China Automobile Industry. In Handbook of Research on Managerial Practices and Disruptive Innovation in Asia (pp. 249-263). IGI Global. 
Jacobsen, W. C., \& Forste, R. (2011). The Wired Generation: Academic and Social Outcomes of Electronic Media Use Among University Students. Cyberpsychology, Behavior, and Social Networking, 14(5), 275-280. https://doi.org/10.1089/cyber.2010.0135

Junco, R. (2012). In-class multitasking and academic performance. Computers in Human Behavior, 28(6), 2236-2243. https://doi.org/10.1016/j.chb.2012.06.031

Koops, W. R. H. (1985). IFLA (International Federation of Library Associations and Institutions). In H. Liebaers, W. J. Haas, \& W. E. Biervliet (Eds.), New Information Technologies and Libraries (pp. 32-33). Springer Netherlands. https://doi.org/10.1007/978-94-009-5452$6 \_8$

Kuznekoff, J. H., \& Titsworth, S. (2013). The Impact of Mobile Phone Usage on Student Learning. Communication Education, 62(3), 233-252. https://doi.org/10.1080/03634523.2013.767917

Lee, S. Y. (2014). Examining the factors that influence early adopters' smartphone adoption: The case of college students. Telematics and Informatics, 31(2), 308-318. https://doi.org/10.1016/j.tele.2013.06.001

Lepp, A., Barkley, J. E., \& Karpinski, A. C. (2015). The Relationship Between Cell Phone Use and Academic Performance in a Sample of U.S. College Students. SAGE Open, 5(1), 215824401557316. https://doi.org/10.1177/2158244015573169

Lo, P., Cho, A., Leung, M., Chiu, D. K. W., Ko, E. H. T., \& Ho, K. K. W. (2016). Use of smartphones by art and design students for accessing library services and learning. Library Hi Tech, 34(2), 224-238. https://doi.org/10.1108/LHT-02-2016-0015

M. Alfawareh, H., \& Jusoh, S. (2014). Smartphones usage among university students: Najran University case. International Journal of Academic Research, 6(2), 321-326. https://doi.org/10.7813/2075-4124.2014/6-2/B.48

Mahmood, H. K., Abbas, J., \& Hussain, F. (2015). Information security management for small and medium size enterprises. Science International-Lahore, 27(3), 2393-2398.

Mahmood, H. K., Hashmi, M. S., Shoaib, D. M., Danish, R., \& Abbas, J. (2014). Impact of TQM Practices on Motivation of Teachers in Secondary Schools Empirical Evidence from Pakistan. Journal of Basic and Applied Scientific Research, 4(6), 1-8.

Mahmood, H. K., Hussain, F., Mahmood, M., Kumail, R., \& Abbas, J. (2020). Impact of EAssessment at Middle School Students' Learning - An Empirical study at USA Middle School Students. International Journal of Scientific \& Engineering Research, 11(4), 17221736.

Muzaffar, A., Abbas, J., Mahmood, H. K., Ramzan, M. A., \& Rizvi, S. S. ul H. (2014). Impact of Technology on Performance of Employees (A Case Study on Allied Bank Ltd, Pakistan). World Applied Sciences Journal, 29(2), 271-276.

Muzaffar, A., Abbas, J., Shoaib, M., \& Mahmood, H. K. (2014). Do Business Schools Really Fulfill Industry Requirements? An Investigation of Industrial Performance of Business Graduates. World Applied Sciences Journal, 31(7), 1378-1384.

Nayak, J. K. (2018). Relationship among smartphone usage, addiction, academic performance and the moderating role of gender: A study of higher education students in India. Computers \& Education, 123, 164-173. https://doi.org/10.1016/j.compedu.2018.05.007

Ng, S. F., Nor, N. H. M., \& Malek, N. A. A. (2017). The Relationship Between Smartphone Use and Academic Performance: A Case of Students in a Malaysian Tertiary Institution. 5(4), 13. 
Reese Bomhold, C. (2013). Educational use of smart phone technology: A survey of mobile phone application use by undergraduate university students. Program, 47(4), 424-436. https://doi.org/10.1108/PROG-01-2013-0003

Safdar, B., Habib, A., Amjad, A., \& Abbas, J. (2020). Treating Students as Customers in Higher Education Institutions and its Impact on their Academic Performance. International Journal of Academic Research in Progressive Education and Development, 9(4), 176191.

Sagsan, M., \& Abbas, J. (2019). Identification of key employability attributes and evaluation of university graduates' performance: Instrument development and validation. Higher Education, Skills and Work-Based Learning, 10(3), 449-466. https://doi.org/10.1108/HESWBL-06-2019-0075

Sağsan, M., \& Abbas, J. (2019). Impact of knowledge management practices on green innovation and corporate sustainable development: A structural analysis. Journal of Cleaner Production, 229, 611-620. https://doi.org/10.1016/j.jclepro.2019.05.024

Vassilakaki, E., Moniarou-Papaconstantinou, V., \& Garoufallou, E. (2016). Identifying the uses of mobile technology among Library and Information Science undergraduate students. Program, 50(4), 417-430. https://doi.org/10.1108/PROG-10-2015-0069

Wai, I. S. H., Ng, S. S. Y., Chiu, D. K. W., Ho, K. K. W., \& Lo, P. (2018). Exploring undergraduate students' usage pattern of mobile apps for education. Journal of Librarianship and Information Science, 50(1), 34-47. https://doi.org/10.1177/0961000616662699 